\title{
Model dan Strategi Pembelajaran Yesus berdasarkan Injil Sinoptikdan Implementasinya bagi Guru Pendidikan Agama Kristen
}

\author{
Yonatan Alex Arifianto \\ Sekolah Tinggi Teologi Sangkakala, Salatiga \\ arifianto.alex@sttsangkakala.ac.id \\ Hardi Budiyana \\ Sekolah Tinggi Teologi Berita Hidup, Surakarta \\ budisttb@yahoo.com \\ Paulus Purwoto \\ Sekolah Tinggi Teologi Torsina, Surakarta \\ pauluspurwoto022@gmail.com
}

\begin{abstract}
Abstarct:
The success of Christian religious education can be observed from the joint corporation between Christian religious education teachers and students and maximizing the teaching which is the goal. Therefore, the role of the teacher in building models and learning strategies for Jesus based on the synoptic Gospels can be applied in the learning process. Using a descriptive qualitative method with a literature study approach, it can be concluded that teachers and all church leaders are expected to be able to convey the value of the Jesus Learning model and strategy for the congregation and students. Because the learning carried out by Jesus in developing spiritual values and can be implemented is what is expected to be maximized in the teaching carried out. Because this is based first on the importance of Christian education, for the congregation's spirituality and for students who continue to aim and focus on Jesus as an example in learning. So that it can bring the role of Christian religious education teachers in learning to explore in studies in the Synoptic Gospels to obtain a Jesus Learning model.
\end{abstract}

Keywords: learning models; strategies; typnotics; christian education

\begin{abstract}
Abstrak:
Keberhasilan pendidikan agama Kristen dapat dicermati dari koorporasi bersama antara guru Pendidikan Agama Kristen dan peserta didik serta memaksimalkan pengajaran yang yang menjadi tujuan tersebut. Oleh karena itu peran guru dalam membangun model dan strategi pembelajaran Yesus berdasarkan Injil sinoptik dapat diterapkan dalam proses pembelajaran. Menggunakan metode kualitatif deskriptif dengan pendekatan studi pustaka maka didapatkan kesimpulan bahwa Guru dan seluruh pimpinan gereja sangat diharapkan dapat menyampaikan nilai dari model dan strategi pembelajaran Yesus bagi para jemaat maupun peserta didik. Sebab pembelajaran yang dilakukan oleh Yesus dalam mengembangkan nilai kerohanian serta dapat di implementasikan menjadi hal yang sangat diharapkan dapat dimaksimalkan dalam pengajaran yang dilakukan. Karena hal tersebut didasari pertama pentingnya pendidikan Kristen, bagi spiritual jemaat maupun peserta didik yang tetap mengarah dan berfokus kepada Yesus sebagai teladan dalam pembelajaran.
\end{abstract}


Sehingga dapat membawa peran guru pendidikan agama Kristen dalam pembelajaran dapat mengeksplore dalam kajian dalam Injil sinoptik untuk didapatkan model Pembelajaran Yesus.

Kata kunci: model pembelajaran; strategi; sipnotik, pendidikan kristen

\section{Pendahuluan}

Pendidikan yang membangun manusia yang seharusnya merupakan usaha nyata dari peran manusia dan usaha yang direncanakan untuk mewujudkan suasana belajar dan segala kegiatan aktivitas pembelajaran yang dapat membawa dampak perubahan. Supaya peserta didik secara bergairah dan termotivasi dalam mengembangkan segala potensi dirinya dengan maksimal. Sehingga memiliki sikap dan nilai spiritual keagamaan, menghidupi pengendalian diri, memiliki kepribadian yang teruji, kecerdasan, akhlak mulia, serta keterampilan yang diperlukan dalam kehidupan bermasyarakat maupun personal. ${ }^{1}$ Pendidikan Agama Kristen dalam lingkup sekolah, keluarga, maupun gereja tidak terlepas dari peran guru sebagai indikator utama dalam meningkatkan pendidikan. Namun dibutuhkan strategi yang merupakan sebuah cara yang dilakukan oleh setiap guru dalam proses belajar mengajar. Menurut Priansa, strategi pembelajaran merupakan suatu tindakan yang direncanakan dan segala sesuatu yang dikerjakan dengan sistematis, serta memanfaatkan berbagai teknik atau metode untuk melengkapi peserta didik dalam mengaktualisasi tujuan pembelajaran yang ditetapkan. Strategi pembelajaran tersebut harus dibuat dengan mempertimbangkan berbagai kondisi yang realita, yang sebenarnya dihadapi dalam proses pembelajaran yang diaktualisasi oleh peserta didik. $^{2}$

Strategi pembelajaran pada intinya merupakan cara yang bangun dan digunakan oleh guru untuk menyampaikan materi kepada peserta didik dengan tujuan materi yang disampaikan akan mudah dipahami, mudah diaplikasikan, dan melekat pada peserta didik. ${ }^{3}$ Strategi mengajar tersebut sangat menolong para guru dalam menyampaikan materi kepada peserta didik agar pembelajaran menjadi lebih efektif. Demikian juga dalam dalam Pendidikan Agama Kristen, proses pembelajarannya membutuhkan metode dan strategi sehingga tujuan pembelajaran dapat tercapai dengan maksimal. Pendidikan yang bertujuan pada tiga aspek pendidikan yaitu pengetahuan (kognitif), keterampilan (psikomotorik) dan sikap (afektif), yang terjadi pada proses belajar mengajar secara terstruktur dan sistematis. ${ }^{4}$ Karena itu pengajar perlu mempersiapkan diri dengan strategi pembelajaran, hal itu akan terlihat dalam proses belajar baik di dalam kelas secara formal maupun dalam

1T Umar and S. L. La Sulo, Pengantar Pendidikan (Jakarta: Rineka Cipta, 2005), 5.

2Priansa and Doni Juni, Pengembangan Strategi Dan Model Pembelajaran (bandung: CV Pustaka Setia, 2017), 88.

${ }^{3}$ Markus Oci, "Strategi Pembelajaran Pendidikan Agama Kristen," Sanctum Domine: Jurnal Teologi 2, no. 1 (2019): 143-160.

4Jhon M. Nainggolan, Menjadi Agama Kristen, (Bandung: Generasi Info Media, 2007), 4. 
kehidupan sehari-hari. Persiapan yang dilakukan dapat mempengaruhi proses belajar mengajar menjadi lebih menarik dan dapat diterima oleh peserta didik. Proses pembelajaran merupakan sebuah situasi di mana terjadi transfer pengetahuan, ilmu dan sebagai bagian mendidik ke arah yang lebih baik dalam pembentukan karakter. Oleh sebab itu, pembelajaran dapat dilakukan dalam lingkungan sekolah secara formal, keluarga, masyarakat, dan gereja, sebab proses transfer pengetahuan dan pembentukan karakter dapat dilaksanakan untuk membawa perubahan peserta didik ke arah yang lebih baik. ${ }^{5}$

Keberhasilan Pendidikan Agama Kristen dapat diwujudkan bila ada kerjasama antara guru dan peserta didik atau murid, serta yang benar-benar menunjukkan kinerja untuk keberhasilan pengajaran yang dilakukannya. Pendidikan Agama Kristen terbuka terhadap sikap dan perubahan serta adanya kebutuhan, sehingga para peserta didik dalam proses pembelajran mampu mengerti dan memahami serta menempatkan diri secara realistis, kritis, dan kreatif dalam setiap situasi dan kondisi yang dihadapi. Termasuk bagaimana cara untuk menempatkan dirinya sebagai orang percaya kepada Tuhan atau pengikut Kristus di tengah-tengah masyarakat sosial dilingkungannya. 6 Terlebih tidak keliru dalam bergaul, baik dalam lingkungan sekolah maupun lingkungan masyarakat. ${ }^{7}$ Orang Kristen juga perlu disadarkan untuk memelihara kadar spiritualitas yang terus dijaga agar tetap bergairah dalam mengiring Tuhan dan senantiasa memerlukan input pembelajaran yang berintegritas, pengajaran yang tidak terkontaminasi dan benar, ${ }^{8}$ dari para guru maupun pemimpin rohaninya. Oleh karena itu, pendidik dapat menyikapi untuk mencontoh konsep strategi dan model pembelajaran Yesus sebagai bagian dari pendidikan yang berdasarkan nilai dan kebenaran Alkitab.

Berkaitan dengan topik model dan strategi pembelajaran Yesus berdasarkan Injil sinoptik dan implementasinya bagi guru Pendidikan Agama Kristen juga pernah diteliti oleh Dina Kristiani dengan penelitian implementasi model teaching learning Tuhan Yesus menurut injil Matius terhadap guru-guru pendidikan Agama Kristen di kota Surakarta. ${ }^{9}$ Kesimpulan dari penelitian tersebut adalah bahwa guru-guru Pendidikan Agama Kristen diharap terus memaksimalkan pembelajaran dengan model Teaching Learning Tuhan Yesus menurut Injil Matius, sehingga menggairahkan

5 I Putu Ayub Darmawan and Diana Kristanti, "Penerapan Model Pembelajaran Picture and Picture Dalam Pembelajaran Di Sekolah Minggu," REGULA FIDEI: Jurnal Pendidikan Agama Kristen 5, no. 1 (2020): 1-12.

${ }^{6}$ Lenda Dabora Sagala, "Peran Pendidikan Agama Kristen Dalam Menghadapi Perubahan Sosial," Jurnal Simpson: Jurnal Teologi dan Pendidikan Agama Kristen 1, no. 1 (2017): 48. 2014), 105.

${ }^{7}$ Moeljono Notosoedirjarjo, Kesehatan Mental, Konsep Dan Penerapan (Malang: UMM Press, (2018): 1 .

8Junihot M. Simanjuntak, “Belajar Sebag.ai Identitas Dan Tugas Gereja,” Jurnal Jaffray 16, no. 1

${ }^{9}$ Dina Kristiani, “Implementasi Model Teaching Learning Tuhan Yesus Menurut Injil Matius Terhadap Guru-Guru Pendidikan Agama Kristen Di Kota Surakarta," Regula Fidei: Jurnal Pendidikan Agama Kristen 3, no. 1 (2018): 1-21. 
anak didik dalam meningkatkan prestasi belajarnya. Donald Samuel Slamet Santosa, Donna Sampaleng, dan Abdon Amtiran melakukan penelitian serupa dalam artikel berjudul Meningkatkan Prestasi Belajar Siswa Melalui Model Pembelajaran. ${ }^{10}$ Dengan kesimpulan bahwa terdapat pengaruh model pembelajaran terhadap prestasi belajar siswa. Berdasarkan kedua penelitian tersebut masih ada hal-hal yang belum diteliti yaitu tentang model dan strategi secara khusus yang dilakukan Yesus di Injil Sipnotik. Oleh sebab itu, artikel ini akan meneliti dan membahas tentang topik tersebut.

Tujuan artikel ini ingin memberi kontribusi bagi pendidik dan seluruh pemimpin agama Kristen yang mengajarkan pendidikan Kristen untuk memahami model dan strategi pembelajaran Yesus. Supaya dapat aplikasikan dalam keseharian, terlebih dalam kurikulum pendidikan gereja maupun sekolah untuk memaksimalkan pendidikan Kristen pada umumnya. Sebab pentingnya belajar dalam kaitannya dengan tugas pembinaan jemaat dan memaknainya sebagai peran tanggung jawab dalam melaksanakan tugas yang urgent $^{11}$ sebab saat ini dunia ada dalam era disrupsi dan dekadensi moral.

\section{Metode}

Metode penelitian dalam artikel ini adalah penelitian kualitatif deskriptif,12 yaitu dengan menggali literatur yang berkaitan dengan konsep model dan strategi pembelajaran Yesus berdasarkan Injil sinoptik. Selain itu penulis juga menggunakan teks-teks paralel dari buku dan jurnal yang mendukung tentang topik tersebut untuk mendapatkan informasi deskriptif tentang model dan strategi pembelajaran. Sehingga penulis dapat mendeskripsikan topik tersebut sebagai kajian berdasarkan firman Tuhan.

\section{Pembahasan}

\section{Pentingnya Pendidikan Kristen}

Pembalajaran Agama Kristen mempunyai dampak yang besar dalam membantu sikap dan prilaku yang mengarah pada pertumbuhan kerohanian. ${ }^{13}$ Terlebih Pendidikan Agama Kristen sangatlah penting untuk diterapkan dalam meningkatkan potensi spiritual, sehingga membantu gereja atau orang percaya agar menjadi manusia yang yang takut akan Tuhan dan hidup mengasihi Tuhan dan

10 Donald Samuel Slamet Santosa, Donna Sampaleng, and Abdon Amtiran, "Meningkatkan Prestasi Belajar Siswa Melalui Model Pembelajaran," SIKIP: Jurnal Pendidikan Agama Kristen 1, no. 1 (2020): 11-24.

11Simanjuntak, "Belajar Sebagai Identitas Dan Tugas Gereja."

12Umrati and Hengki Wijaya, Analisis Data Kualitatif Teori Konsep Dalam Penelitian Pendidikan (Sulawesi Selatan: Sekolah Tinggi Theologia Jaffray, 2020), 12.

${ }^{13}$ Lilis Ermindyawati, "Peranan Guru Pendidikan Agama Kristen Terhadap Perilaku SiswaSiswi Di SD Negeri 01 Ujung Watu Jepara," FIDEI: Jurnal Teologi Sistematika dan Praktika 2, no. 1 (2019): 40-61. 
sesama. ${ }^{14}$ Orang percaya perlu disadarkan bahwa untuk tetap menjaga iman dan kerohanian maka diperlukan pendidikan Kristen yang dapat mengubah hidup serta mendasari peserta didik untuk tetap berada dalam ajaran yang yang benar saat menjalani kehidupannya. Pendidikan Agama Kristen merupakan proses pengajaran dan pembelajaran yang menyangkut kerohanian dan nilai-nilai moral serta spiritual yang berdasarkan firman Allah yang berpusat pada Kristus. Pendidikan Agama Kristen juga berperan untuk membawa peserta didik secara personal menuju pada pengenalan akan Tuhan dan kedewasaan rohani dalam Kristus. ${ }^{15}$ Semua tersebut selaras dengan kerinduan Allah bahwa orang percaya harus dapat menjadi berkat dan berbuat kebaikan bagi dirinya sendiri, orang lain dan yang terpenting nama Tuhan dipermuliakan lewat tindakannya. ${ }^{16}$ Pendidikan Agama Kristen sebagai bagian dari tugas didaskalia gereja. Untuk itu gereja yang memberikan respon positif dalam pengajaran dapat memberi sumbangsihnya bagi dunia pendidikan agama dimanapun, dengan terus memperlengkapi semua program pendidikan agama Kristen bagi semua kategori usia dan berbagai situasi baik yang dilakukana dalam keluarga, gereja dan sekolah.

Pendidikan Agama Kristen dalam keluarga diharapkan juga dapat memberikan nilai pengajaran iman dan nilai-nilai moral. Yang selaras dengan Firman. ${ }^{17}$ Sehingga melalui peran materi pengajaran yang bersumber dari kebenaran Alkitab dapat membentuk kepribadian yang berkualitas dan memiliki kedewasaan rohani yang kuat untuk menghadapi apapun rintangan. Pendidikan itu juga mengajarkan pentingnya pengharapan akan jalan Tuhan dan solusi ketika menghadapi rintangan. Secara Alkitabiah konsep pendidikan dan segala rintangannya dihadirkan supaya memberi dampak positif bagi manusia dalam membangun hubungan dan pengenalan akan Tuhan. ${ }^{18}$ Seiring dengan perubahan dalam berbagai kehidupan masyarakat, diharapkan Pendidikan Agama Kristen menjadi sarana penting untuk pembentukan spiritualitas peserta didik, agar mampu membawa dirinya menjadi berdampak, serta berperan aktif di dunia yang multikultural. ${ }^{19}$

Pendidikan Agama Kristen adalah konsep dan sebagai proses pembelajaran yang menuju kepada pendidikan yang bercirikan moral-moral kristiani yang

${ }^{14}$ Ibid.

${ }^{15}$ Semion Nuh, I Putu Ayub Darmawan, and Edi Sujoko, "Implementasi Pak Konteks Gereja Di Gkii Tandang, Semarang," Pengarah: Jurnal Teologi Kristen 1, no. 1 (2019): 59-70.

${ }^{16}$ Simanjuntak, "Belajar Sebagai Identitas Dan Tugas Gereja."

${ }^{17}$ Ruwi Hastuti, "Pendidikan Agama Kristen Dalam Keluarga Sebagai Pusat Bermisi," Jurnal Antusias 2, no. 4 (2013): 23-68.

${ }^{18}$ Yonatan Alex Arifianto, "Pentingnya Pendidikan Kristen Dalam Membangun Kerohanian Keluarga Di Masa Pandemi Covid-19," Regula Fidei Jurnal Pendidikan Agama Kristen 5, no. 2 (2020): 94106. 2009), 13.

${ }^{19}$ John M. Nainggolan, PAK Dalam Masyarakat Majemuk (Bandung: Bina Media Informasi, 
berdasarkan Alkitabiah, yang memiliki pengertian bahwa materi pengajaran Pendidikan Agama Kristen merupakan materi yang berisi tentang nilai-nilai yang konkrit dari kebenaran iman Kristen. ${ }^{20}$ Pendidikan Agama Kristen memberikan prioritas bagi peserta didik untuk dibekali dengan pengetahuan (kognitif), yang bertujuan agar mengetahui tangungjawab personal sebagai peserta didiki dalam meningkatkan kualitas hidup. Peserta didik juga diberikan penanaman sikap yang mendasar supaya menjadi pribadi yang beradab (afektif) dengan tujuan agar memahami penilaian baik buruk, benar salah sehingga mampu membedakan segala sesuatu yang berguna. Serta peserta didik dilatih keterampilannya (psikomotorik) sehingga memiliki kemampuan dalam melakukan tugas dan tanggungjawab yang dipercayakan oleh Tuhan Yesus. ${ }^{21}$ Pendidikan Agama Kristen yang diterapkan di kawasan formal harus menekankan kognitif yang dapat memberi pemahaman kepada peserta didik untuk mengenal pribadi Tuhan Yesus sebagai Pencipta dan Juru Selamat. Juga peran Pendidikan Agama Kristen diarahkan kepada pembentukan kedewasaan kerohanian dan terlebih pertumbuhan karakter yang didasari dari perkataan Tuhan dalam FirmanNya. ${ }^{22}$

\section{Yesus sebagai Teladan dalam pembelajaran}

Kasih dan kuasa Allah telah diberikan kepada manusia di dalam karya pengorbanan Yesus Kristus. Sehingga memberikan pilihan kepada semua orang untuk memilih dengn konsekunsinya. Sebab barang siapa yang percaya kepada-Nya akan diselamatkan dan bila tidak percaya akan dihukum. Itulah kepercayaan yang mutlak dari kekritenan. Karena hal itu yang mendasari semua kegiatan orang percaya, tidak terkecuali di dalam penyelenggaraan kegiatan dalam pendidikan agama Kristen. ${ }^{23}$ Dalam pelayanan Tuhan Yesus ketika berada di dunia, Dia meninggalkan banyak teladan yang seharusnya diikuti oleh setiap orang percaya. Salah satu yang disematkan pada diri Yesus adalah Guru Agung. Sebagai Guru Agung, Yesus mengajar dengan penuh kuasa yang ada pada-Nya. Selain memiliki kuasa, Yesus juga dalam mengajar selalu menggunakan beberapa metode untuk membangun kontak dengan pendengar-Nya. ${ }^{24}$ Yesus memberikan suatu tujuan yang jelas kepada umatNya agar setiap manusia saling mengasihi dan terlebih memberi dampak lewat bersaksi dan melayani seperti teladan Yesus kepada murid-murid-Nya. ${ }^{25}$ Sebab Tuhan

20Rifai, "Pendidikan Kristen Dalam Membangun Karakter Remaja Di Sekolah Menengah," Antusias-Jurnal Teologi dan Pelayanan 2, no. 2 (2012): 1-17.

${ }^{21}$ Ibid.

22Ibid.

${ }^{23}$ sairin weinata, Identitas \& Ciri Khas Pendidikan Kristen Di Indonesia (jakarta: BPK Gunung Mulia, 2010), 12.

${ }^{24}$ Marsi Bombongan Rantesalu and Hesti Arista Dara, "Penerapan Model Pembelajaran Yesus Dalam Matius 7:24-29 Terhadap Hasil Belajar Siswa Di Smpn 12 Kota Kupang," EDULEAD: Journal of Christian Education and Leadership 1, no. 1 (2020): 92-107.

25Sagala, "Peran Pendidikan Agama Kristen Dalam Menghadapi Perubahan Sosial." 
Yesus sebagai Pribadi Guru Agung selalu mengajarkan sikap yang benar baik tentang iman maupun sikap mengasihi Allah kepada para pendengar-Nya. ${ }^{26}$

Keteladan Yesus yang harus di ikuti adalah mengajar dengan dedikasi yang tinggi, Yesus juga memberikan keteladan sikap yang mengasihi dan juga sikap melayani. Keteladan ini harusnya diikuti oleh seluruh pendidik agama Kristen.

\section{Peran Guru Pendidikan Agama Kristen dalam Pembelajaran}

Tanggung jawab dan peran penting pendidik merupakan tugas yang mulia yaitu membantu peserta didik agar dapat memaksimalkan seluruh talenta maupun potensi yang dimilikinya. Talenta maupun potensi peserta didik dikembangkan bukan hanya bersinggungan dengan masalah kecerdasan dan keterampilan, melainkan menyangkut seluruh aspek personal dalam membawa kepribadian sebagai manusia. ${ }^{27}$ Guru tidak hanya dituntut untuk memiliki pengertian atau pemahaman dalam menggunakan kemampuan di bidang pembelajaran, namun juga guru harus memotivasi peserta didik supaya lebih maksimal dalam proses pembelajaran. ${ }^{28}$ Guru Pendidikan Agama Kristen juga diharapkan untuk berberperan dalam mengajarkan nilai-nilai spritual dan memotivasi peserta didiknya. ${ }^{29}$ Guru Pendidikan Agama Kristen harus memahami dasar dan konsep motivasi sehingga guru mampu berperan sebagai fasilitator perkembangan peserta didik, baik yang menyangkut aspek intelektual, emosional, sosial, maupun mental spiritual. ${ }^{30}$

Dalam Pendidikan Agama Kristen guru harus selalu menyampaikan kebenaran dengan lugas dan terlebih menjadi pribadi yang menghidupi kebenaran tersebut serta yang terpenting menjadi sarana untuk membimbing. ${ }^{31}$ Proses pembelajaran merupakan bagian dari esensi dan hakikat manusia untuk berkembang didasari dari tuntutan dasarnya dari Tuhan untuk mengenal Dia sebagai Tuhan, yang menciptakan dan juga Tuhan yang menyelamatkan manusia melalui karya penebusan. ${ }^{32}$ Terlebih pendidikan Kristen berpusat pada tanggung jawab untuk mengerti dan mengamalkan serta mengkomunikasikan penyataan Allah (God's revelation) di dalam Alkitab dan di dalam Yesus Kristus. ${ }^{33}$ Sehingga pesan nilai dari Alkitab dapat disebarkan ke lingkungan yang lebih luas. ${ }^{34}$ Selain itu seorang guru Pendidikan Agama Kristen

26Hastuti, "Pendidikan Agama Kristen Dalam Keluarga Sebagai Pusat Bermisi."

${ }^{27}$ Esther Rela Intarti, "Peran Guru Pendidikan Agama Kristen Sebagai Motivator," Regula Fidei 1, no. 2 (2016): 28-40.

${ }^{28}$ Ibid.

${ }^{29}$ Ibid.

30Ibid.

${ }^{31}$ Mark Phillips Eliasaputra, Martina Novalina, and Ruth Judica Siahaan, "Tantangan

Pendidikan Agama Kristen Di Era Revolusi Industri 4.0 Dan Pasca Kebenaran," BONAFIDE: Jurnal Teologi dan Pendidikan Kristen 1, no. 1 (2020): 1-22.

32Simanjuntak, "Belajar Sebagai Identitas Dan Tugas Gereja."

${ }^{33}$ Ibid.

${ }^{34}$ Daniel Stefanus, Pendidikan Agama Kristen Kemajemukan (bandung: BMI Bina Media Informas, 2009), 40-50. 
harus memiliki kemampuan mengajar secara kreatif yang meliputi banyak hal seperti memiliki sifat yang mencerminkan pengenalan akan Tuhan dan firman-Nya, sebagai guru juga harus mampu mempersiapkan pelajaran dengan cara merencanakan isi pelajaran, kemampuan dalam menggunakan metode-metode mengajar, ${ }^{35}$ segala hal model maupun strategi mengajar yang didasarkan pada sang guru Agung yaitu Yesus Kristus. Sebab metode dan strategi pembelajaran Yesus dalam Injil Sinoptik dapat menjadi acuan dan landasan yang relevan disepanjang masa. Sehingga guru Pendidikan Agama Kristen dapat memberikan motivasi belajar yang dapat mempengaruhi hasil belajar peserta didik. Karena seseorang yang tidak mempunyai motivasi dalam belajar, tidak mungkin dapat melakukan aktivitas belajar dengan baik. ${ }^{36} \mathrm{Hal}$ itu didasari dari terdorongnya seseorang melakukan sebuah kegiatan, akan berjalan bersama dengan motivasi yang kuat.

Motivasi yang akan menggerakan untuk mencapai maksud dengan memanfaatkan segala kapabilitas dan kapasitas yang dapat dilakukan. Tinggi rendahnya motivasi selalu dijadikan indikator terhadap tinggi rendahnya prestasi belajar peserta didik. ${ }^{37}$ Guru Pendidikan Agama Kristen juga harus meneladani Yesus dalam hal mempelajari karakter setiap peserta didiknya. ${ }^{38}$ Karena pendidikan karakter harus ditanamkan sejak dini. ${ }^{39}$ Keteladanan yang diberikan Yesus sebagai Guru yang sempurna dan tidak ada bandingannya di dunia baik dalam karakter kehidupan maupun dalam metode dan strategi mengajar, sebab Yesus memiliki kompetensi pedagogik sepanjang zaman yang dapat diterapkan dalam pembelajaran pendidikan kerohanian maupun dalam segala aspek dalam pendidikan. ${ }^{40}$

\section{Model Pembelajaran Yesus}

Yesus dalam Injil, dapat dikatakan telah menyediakan sebuah lingkungan belajar yang tidak monoton, hal ini terlihat dari setiap proses pembelajaran yang Dia lakukan secara langsung berhadapan dengan lingkungan yang bervariasi, baik berupa lingkungan fisik maupun sosial. ${ }^{41}$ Sebab peran model dan strategi Yesus dalam mengajar membawa perubahan dan berdampak serta berpengaruh. Oleh karena itu

\footnotetext{
35Janet Kuhns, “Mengajar Secara Kreatif," Jurnal Jaffray 1, no. 1 (January 5, 2005): 90, http://ojs.sttjaffray.ac.id/index.php/JJV71/article/view/171.

${ }^{36}$ Saptono Yohanes Joko, "Motivasi Dan Keberhasilan Belajar Siswa," Jurnal pendidikan agama kristen I, no. 1 (2016): 189-212.

${ }^{37}$ Ibid.

${ }^{38}$ Ronald Yohanes Sinlae, "Kompetensi Pedagogik Tuhan Yesus Dalam Injil Matius Pasal 5-7," Excelsis Deo: Jurnal Teologi, Misiologi, dan Pendidikan 4, no. 1 (2019): 35-55.

39Puji Asmaul Chusna, "Pengaruh Media Gadget Pada Perkembangan Karakter Anak," Dinamika Penelitian: Media Komunikasi Sosial Keagamaan 17, no. 2 (2017): 315-330.

${ }^{40}$ Harianto GP, Pendidikan Agama Kristen Dalam Alkitab Dan Dunia Pendidikan Masa Kini (Yokyakarta: Penerbit Andi, 2012), 38.

${ }^{41}$ Karnawati, Hosana, and I Putu Ayub Darmawan, "Lingkungan Proses Pembelajaran Yesus," Veritas Lux Mea: Jurnal Teologi dan Pendidikan Kristen 1, no. 2 (2019): 76-89, http://jurnal.sttkn.ac.id/index.php/Veritas/article/view/46/pdf.
} 
model pembeljaran Yesus juga akan berdampak positif dalam kepribadian anak. ${ }^{42}$ Adapun model pembelajaran Yesus dalam Injil Sinoptik antara lain:

\section{Model Pembelajaran Kooperatif (Cooperative Learning)}

Model pembelajaran koperatif ini diarahkan sesuai dengan hakikat manusia sebagai makhluk yang memiliki sosial dan sebagai makluk yang saling tergantung individu kepada individu lainnya. Serta makluk yang mempunyai tujuan dan peran tanggung jawab bersama. Dengan situasi yang real tersebut, metode belajar berkelompok secara koperatif, peserta didik dapat dilatih dan dibiasakan untuk saling berbagi (sharing) pengetahuan, pengalaman, tugas, tanggung jawab. ${ }^{43}$ Tuhan Yesus membawa suatu perubahan yang sangat fundamental bagi setiap orang yang Ia temui, respon yang kooperatif dari setiap pribadi kepada Yesus membawa perubahan hidup. Kooperatif yang Yesus terapkan juga didasari oleh respon yang benar dari manusia. Yesus sebagai Guru Agung yang layak diteladani dalam seluruh aspek kehidupanNya. ${ }^{44}$ Metode lain dalam model kooperatif learning ada metode bimbingan Yesus mengajar murid-murid-Nya dengan ceramah, namun juga Yesus memberi bimbingan kepada mereka. Yesus berceramah kepada murid-murid-Nya kemudian membimbing mereka untuk mengamalkannya apa yang sudah diterima. Sebagai contoh Yesus mengajar dengan metode bimbingan dalam Matius 10.

\section{Model Pembelajaran Kontektual (Contextual Teaching and Learning)}

Model pembelajaran kontekstual, merupakan pembelajaran yang dimulai dengan esensi yang berbasis tanya jawab lisan yang terkait dengan dunia nyata dalam kehidupan. Pada konsep dan prinsipnya pembelajaran kontekstual adalah aktivitas dalam melakukan dan mengalami, tidak hanya menonton dan mencatat, dan pengembangan kemampuan sosialisasi. ${ }^{45}$ Model pembelajaran ini dapat dipraktekan dengan metode apa yang Yesus lakukan yaitu: pertama, metode tanya jawab. Metode tanya jawab adalah salah satu metode yang sering dipergunakan oleh Tuhan Yesus dalam mengajar. Metode ini memang telah banyak dipakai oleh para guru atau Rabi sejak lama. Metode ini dalam Injil Matius 22:34-40 dipaparkan tentang tanya jawab orang-orang Farisi kepada Tuhan Yesus mengenai hukum yang terutama. Sekalipun pertanyaan yang mereka ajukan hanya untuk mencobai Tuhan Yesus, namun sebagai Guru yang baik, Ia menjawab dengan bijaksana dan tepat. Matius 21:23-27 merupakan

42Singgih D. Gunarsa, Psikologi Praktis Anak, Remaja,Dan Keluarga (Jakarta: BPK Gunung Mulia, 2004), 106-108.

${ }^{43}$ Muhammad Fathurrohman, “Model-Model Pembelajaran,” Universitas Negeri Yogyakarta. Jogjakarta: Ar-Ruzz Media. Retrieved from (2015).

${ }^{44}$ Dina Kristiani, “Implementasi Model Teaching Learning Menurut Injil Matius Terhadap Guru-Guru Pendidikan Agama Kristen Di Kota Surakarta," Jurnal Pendidikan Agama Kristen 3, no. 1 (2018): 438-458.

45 Ibid. 
pertanyaan dari imam-iman kepala serta tua-tua bangsa Yahudi mengenai dari mana kuasa Yesus melakukan segala perbuatan-Nya. Tuhan Yesus tahu bahwa sebenarnya mereka hanya ingin menjebak-Nya. ${ }^{46}$

Kedua, metode diskusi. Tuhan Yesus juga sering menggunakan metode diskusi untuk melihat respons dari para pendengar-Nya (Lukas 2: 40-52) dan Yesus berdiskusi juga tentang hal-hal yang sudah Ia ajarkan, atau Ia juga memberikan kesempatan kepada para murid untuk mendiskusikan hal yang penting. Namun demikian pelaksanaan metode diskusi yang dipakai Tuhan Yesus masih sederhana dan belum tertata rapih seperti yang sering diselenggarakan dalam dunia pendidikan sekarang ini. Metode diskusi adalah metode pengajaran yang menghadapkan anak didik pada suatu permasalahan. Tujuan utama metode ini adalah untuk memecahkan suatu permasalahan, menjawab pertanyaan, menambah dan memahami pengetahuan anak didik serta untuk membuat suatu keputusan. ${ }^{47}$ Metode dialog yang dipakai oleh Yesus merupakan cara yang dipakai Yesus untuk meberikan jawaban-jawaban atas pertanyaan-pertanyaan yang disampaikan kepada-Nya. 48

\section{Model Pembelajaran Cerita}

Pribadi Tuhan Yesus merupakan ahli menyampaikan kebenaran dalam bercerita. Pengajaran-Nya memacu personal demi personal untuk terus pikiran; bukan mendowngrade pikiran. Metode ini kerap dibawahkan dengan perumpamaan dalam istilah dan bentuk yang paling terkenal dari ciri-ciri ajaran-Nya yang secara kreatif melibatkan setiap personal dalam proses belajar. Seperti metode perumpamaan mengenai kehidupan dituturkanoleh Yesus dalam cerita dengan naratif dan piguratif dipakai oleh Tuhan Yesus dalam kitab Injil. ${ }^{49}$ Markus mencatat bahwa Yesus, mengajarkan banyak hal dalam perumpamaan (Markus 4:2). Dalam mengajar Yesus menggunakan beberapa metode seperti yang terdapat dalam Matius 7:24- 29. Dalam bagian ini Yesus menyampaikan khotbah-Nya dengan menggunakan metode ceramah, metode bercerita, dan menggunakan metode perumpamaan. ${ }^{50}$

Yesus dalam model pembelajaran cerita juga menggunakan metode ceramah. Tuhan Yesus sering memakai metode ceramah atau metode khotbah, dalam menjelaskan ajaran-Nya kepada para murid-Nya maupun saat mengajar orang banyak. Misalnya, khotbah Tuhan Yesus di atas bukit dalam Injil Matius 5- 7. Matius

${ }^{46}$ Ibid.

47Ibid.

${ }^{48}$ Daniel Sutoyo, "Implementasi Metode Pengajaran Tuhan Yesus Dalam Injil-Injil," Antusias: Jurnal Teologi dan Pelayanan 1, no. 1 (2011): 41-96.

${ }^{49}$ Kristiani, “Implementasi Model Teaching Learning Menurut Injil Matius Terhadap GuruGuru Pendidikan Agama Kristen Di Kota Surakarta."

${ }^{50 I m a n u e l ~ A g u n g ~ a n d ~ M a d e ~ A s t i k a, ~ " P e n e r a p a n ~ M e t o d e ~ M e n g a j a r ~ Y e s u s ~ M e n u r u t ~ I n j i l ~}$ Sinoptik Dalam Pelaksanaan Pendidikan Agama Kristen Di SMA Gamaliel Makassar," Jurnal Jaffray (2011). 
24-25 merupakan khotbah Tuhan Yesus tentang akhir jaman. Tuhan Yesus sebagai Guru Agung justru lebih dahulu menerapkan prinsip-prinsip dalam memakai metode ceramah, sehingga hasilnya sangat memuaskan. ${ }^{51}$ Metode ceramah Yesus, bertujuan untuk menyampaikan, pengetahuan kepada murid-murid-Nya atau menafsirkan pengetahuan tersebut. Dengan metode ceramah ini Yasus mengharapkan supaya murid-murid-Nya. ${ }^{52}$ Dengan metode ceramah Yesus berusaha menyampaikan pengetahuan kepada murid-muridNya atau menafsirkan pengetahuan tersebut dan dalam Metode perumpamaan ini merupakan cara Yesus menyampaikan pesan yang paling sederhana dan mudah diingat oleh pendengarnya. ${ }^{53}$

Metode ini memiliki satu identik khusus yang mengesankan dari setiap pelayanan Tuhan Yesus. Metode ini sangat menarik bagi perhatian dan antusias orang banyak dalam jumlah yang besar. ${ }^{54}$ Leroy Ford mengungkapkan bahwa metode ceramah merupakan suatu pidato yang dinyatakan dengan suara yang jelas oleh seorang pembicara dihadapan sekelompok pendengar dengan tujuan dan pesan yang dapat langsung diterima. ${ }^{55}$ Melalui metode ceramah ini Tuhan Yesus berusaha menyampaikan kebenaran dalam pengetahuan kepada setiap orang yang dijumpai, baik dalam skala kecil maupun skala besar. Bahkan Tuhan Yesus memberikan pengetahuan yang dapat ditafsirkan dalam pengetahuan tersebut. Melalui metode ini Tuhan Yesus mengharapkan dua tanggapan dari para murid-murid, yaitu pengertian mendalam dan perilaku baru yang harus diaplikasikan dalam kehidupan sehari-hari (Mat 5-7). Melalui metode ceramah ini Tuhan Yesus juga memberikan pengajaran serta memberikan pendampingan kepada murid-murid-Nya. ${ }^{56}$ Melalui metode ceramah juga, diharapkan guru lebih aktif berbicara dan murid diharapkan juga menyimak walau cenderung pasif hanya diam mendengarkan. Akan tetapi dalam metode ceramah harus meneladani sikap dan ajaran Yesus, dimana setiap memulai pengajarannya Ia menggunakan pendahuluan yang menarik yaitu mengungkapkan kata-kata yang sangat penting. ${ }^{57}$ Hal itu supaya merangsang personal yang mendengar-Nya.

\section{Model Pembelajaran Berbasis Masalah}

Metode pembelajaran berbasis masalah adalah salah satu dari banyak metode dalam pembelajaran yang menggunakan persoalan atau permasalahan sebagai

\footnotetext{
${ }^{51}$ Kristiani, “Implementasi Model Teaching Learning Menurut Injil Matius Terhadap GuruGuru Pendidikan Agama Kristen Di Kota Surakarta."

52Sutoyo, "Implementasi Metode Pengajaran Tuhan Yesus Dalam Injil-Injil."

53Daniel Nuhamara, Pembimbing PAK (Bandung: Jurnal Info Media, 2007), 137.

${ }^{54}$ Rick Warren, The Purpose Driven Church (Malang: Gandum Mas, 2004), 213.

${ }^{55}$ Leroy Ford, A Primer For Teaching and Leaders (Bandung: Lembaga Literatur Baptis Indonesia, 1998), 56.

${ }^{56}$ Nuhamara, Pembimbing PAK, 138.

${ }^{57}$ Sinlae, "Kompetensi Pedagogik Tuhan Yesus Dalam Injil Matius Pasal 5-7."
} 
permulaan dalam mengumpulkan keterangan dalam proses pembelajaran sehingga dapat mengintegrasikan pengetahuan baru. ${ }^{58}$ Model pembelajaran ini merupakan metode pembelajaran yang ditandai oleh adanya persoalan atau masalah nyata, a realworld problems sebagai konteks bagi mahasiswa untuk belajar kritis dan keterampilan memecahkan masalah dan memperoleh pengetahuan. ${ }^{59}$ Model ini juga diterapkan oleh Yesus dengan bersamaan dengan metode demonstrasi, sebab metode demonstrasi merupakan metode yang paling efektif, untuk membantu peserta didik untuk diajar mencari jawaban dari persoalan tersebut dengan usaha sendiri berdasarkan fakta atau data yang benar yang ditemukan. ${ }^{60}$ Terlebih untuk bertindak dengan data dan rasional sebagai kajian sehingga peserta didik mampu melihat peluang untuk menyelesaikan setiap masalah dengan belajar dari data dan fakta yang terjadi.

\section{Model Perjumpaan}

Model pembelajaran yang dimaksud dengan metode perjumpaan dalam pengajaran Yesus adalah para peserta didik ditantang secara langsung untuk mengambil keputusan saat proses pembelajaran terjadi. ${ }^{61}$ Seperti yang dilakukan Yesus saat menantang orang Farisi, "Jadi pergilah dan pelajarilah arti firman ini: Yang Kukehendaki ialah belas kasihan dan bukan persembahan" (Matius 9:13). Dalam proses pembelajaran perjumpaan Tuhan Yesus tidak pernah memaksakan keputusankeputusan-Nya, namun Ia mengharapakan setiap personal untuk mengambil keputusan. Sebab sejatinya pengajaran yang baik itu berperan untuk menolong peserta didik agar bertanggung jawab atas pemikiran dan hidupnya. Konsep ini memberikan pemahaman kepada orang percaya bahwa Tuhan Yesus selamanya akan mendorong dan memampukan orang lain untuk membuat keputusan terbaik yang mungkin bisa dilakukan. Metode perjumpaan ini dilakukan Tuhan Yesus terhadap setiap perjumpaannya dengan manusia untuk memberikan pesan penting yang dalam yang digunakan dan dipilih untuk menyesuaikan dengan situasi dan kebutuhan dari pendengar-Nya. Setiap pertemuan sangatlah berbeda karena Yesus tahu apa yang ada dalam diri setiap orang secara umum dan secara individu. Seperti percakapan dengan Nikodemus dan perwira di Kapernaum. Yesus dalam hal ini juga memberikan pernyataan yang benar-benar ditekankan pada perjumpaan dengan wanita pendaharaan (Markus 5:29-30). Model perjumpaan yang dilakukan oleh Yesus kepada orang yang ditemui memberikan perubahan pola pikir dan tindakan sebab

\footnotetext{
${ }^{58}$ Fathurrohman, "Model-Model Pembelajaran."

${ }^{59} \mathrm{Ibid}$.

${ }^{60}$ Kristiani, “Implementasi Model Teaching Learning Menurut Injil Matius Terhadap GuruGuru Pendidikan Agama Kristen Di Kota Surakarta."

${ }^{61}$ Sutoyo, "Implementasi Metode Pengajaran Tuhan Yesus Dalam Injil-Injil."
} 
perjumpaan Yesus dan setiap pribadi itu menekankan pada hubungan pembelajaran yang masuk dengan sentuhan kuasa lewat perkataan langsung Yesus kepada mereka.

\section{Model Perbuatan Simbolis}

Sebelum Yesus mengadakan pelayanan di depan umum, Yesus dibaptis oleh Yohanes Pembaptis. Dengan perbuatan simbolis ini muncullah pertanyaan dalam diri orang-orang Yahudi pada saat itu dan menjadikan bingung para ahli sekarang ini. Sebab baptisan Yohanes adalah baptisan pertobatan seseorang dari dosa-dosanya, bagaimana dengan Yesus?62 Yesus mengutuk pohon Ara juga dapat dinyatakan sebagai model simbolis. Metode peragaan dalam proses pengajaran-Nya, Tuhan Yesus juga memakai metode peragaan. Metode peragaan digunakan untuk menunjukkan dan memperagakan obyek-obyek yang konkrit agar dilihat langsung oleh para muridNya. ${ }^{63}$ Model dan strategi pembelajaran Yesus ini memberikan pesan bahwa hal-hal simbolis dapat menjadi pembelajaran yang dapat membawa pada pengertian yang benar.

\section{Model Pembelajaran Probing-Prompting}

Model pembelajaran ini merupakan metode yang melibatkan cara guru dalam memberi serangkaian pertanyaan yang sifatnya membimbing dan untuk menggali informasi yang akurat, sehingga terjadi proses berpikir yang mengakitkan pengetahuan setiap siswa dan pengalamannya dengan pengetahuan baru yang sedang dipelajari. Pertanyaan siapa Aku ini kepada murid-murid-Nya, melahirkan statement dari Petrus bahwa Ia adalah Mesias. Yesus mengajarkan juga kepada muridnya tentang Kota Yerusalem yang ditangisinya sebagai pembelajaran kepada murid-muridnya. Yesus juga menggunakan metode teka-teki (Matius 11:12). Konsep pembelajaran Yesus dapat juga diaplikasikan dalam pembelajaran oleh guru dan peserta didik sebagai bagian untuk menjawab apa yang ditanyakan dengan teka-teki untuk membawa para peserta didik berpikir kritis.

\section{Model Examples Non Examples}

Model ini menampilkan guru sebagai pendidik mempunyai peran fasilitator pendidikan terhadap para peserta didik dalam mencermati sajian, diskusi kelompok tentang sajian konsep gambaran yang jelas, dan mencermati presentasi hasil kelompok, kesimpulan, evaluasi dan refleksi bagi proses pembelajaran yang diterima. Metode ini seperti metode apologetika terhadap beberapa kasus yang harus di counter. Model ini seperti pengajaran Yesus yang ditekankan dalam ketaatan terhadap pemerintahan dalam hikmat dan kebijaksanaan Ilahi, Yesus meminta kepada mereka untuk menunjukkan uang dinar. Di permukaan uang dinar terdapat gambar dan

\footnotetext{
${ }^{62}$ Ibid.

${ }^{63}$ Kristiani, “Implementasi Model Teaching Learning Menurut Injil Matius Terhadap GuruGuru Pendidikan Agama Kristen Di Kota Surakarta."
} 
tulisan kaisar. Kemudian Yesus berkata: “Berikanlah kepada Kaisar apa yang wajib kamu berikan kepada Kaisar, dan kepada Allah apa yang wajib kamu berikan kepada Allah" (Lukas 20:22). Hasil dari pencerahan yang Yesus lakukan dalam model pembelajaran ini memberikan dampak pengertian dan sikap yang dapat diaplikasikan untuk mentaati pemerinta dan juga Tuhan. Dibalik pernyataan Yesus dari pertanyaan yang menjebak ada jawaban Yesus yang bernilai kebenaran yang mutlak dan yang luar biasa (Mat. 22:15-22).

\section{Model pembelajaran SAVI}

Model pembelajaran SAVI ini memprioritaskan bahwa proses pembelajaran haruslah memanfaatkan secara cermat semua alat indra yang dimiliki peserta didik. Makna dari istilah SAVI ini merupakan kependekan dari: Somatic yang bermakna gerakan tubuh (hands-on, aktivitas fisik) di mana proses belajar dapat menghasilkan pemikiran yang di aktulisasi dengan gerak fisik serta mengalami dan melakukan. Selanjutnya adalah Auditory yang memiliki arti bahwa proses pembelajaran haruslah dengan proses mendengarkan, menyimak secara cermat, berbicara, presentasi, argumentasi, mengemukakan ide dan pendapat, serta menanggapi apa yang telah terjadi dalam proses pembelajaran. Selanjutnya adalah Visualization yang memiliki makna proses belajar haruslah menggunakan indra penglihatan yaitu mata yang diterapkan melalui pengamatan, menggambar, mendemonstrasikan, membaca, menggunakan media dan alat peraga. Makna dari istilah yang terakhir adalah Intellektual yang mempunyai arti proses belajar diharapakan menggunakan kemampuan berpikir (minds-on) dan belajar haruslah dengan konsentrasi pikiran dan berlatih menggunakannya melalui menyelidiki, mengidentifikasi, bernalar, menemukan, menemukan hal baru, mengkonstruksi, memecahkan setiap problem, dan menerapkan setiap hal yang sudah dilalui dalam proses pembelajaran.

Metode ini juga disematkan kepada pertanyaan orang Yahudi kepada Yesus tentang siapa sesamaku, dan Yesus menjawab dengan perumpamaan yang mengarah kepada nalar untuk tahu orang Samaria yang baik dapat menjadi contoh dalam menjalani kehidupan (Lukas 9:51-56).

\section{Kesimpulan}

Guru dan seluruh pimpinan gereja sangat diharapkan dapat menyampaikan nilai dari model dan strategi pembelajaran Yesus bagi para jemaat maupun peserta didik, sebab pembelajaran yang dilakukan oleh Yesus dalam mengembangkan nilai kerohanian serta dapat diimplementasikan menjadi hal yang sangat diharapkan dapat dimaksimalkan dalam pengajaran yang dilakukan. Karena hal tersebut didasari pentingnya pendidikan Kristen, bagi spiritual jemaat maupun peserta didik yang tetap mengarah dan berfokus kepada Yesus sebagai teladan dalam pembelajaran. Sehingga dapat membawa peran guru Pendidikan Agama Kristen dalam 
pembelajaran untuk menambah wawasan baru di setiap kajian dalam Injil sinoptik yang didapat dari prinsip dan model pembelajaran Yesus.

Model pembelajaran Yesus sangat menjadi inspirasi dan nilai bagi pertumbuhan rohani maupun konsep pengajaran yang menekankan metode dan strategi pembelajaran yang dapat diterapkan bagi semua kalangan. Model dan strategi pembelajaran Yesus bagi pendidik dan seluruh pemimpin agama Kristen yang mengajarkan pendidikan Kristen untuk dapat menerapkan dan memberikan kontribusi bagi dunia pendidikan. Strategi dan model pembelajaran Yesus yang diaktualisasi dalam dunia pendidikan mampu memecahkan persoalan dalam kehidupan sehari-hari dalam meningkatkan pendidikan. Untuk itu, guru Pendidikan Agama Kristen dapat memahami model dan strategi pembelajaran Yesus, supaya dapat memaksimalkan pendidikan Kristen.

\section{Rujukan}

Agung, Imanuel, and Made Astika. “Penerapan Metode Mengajar Yesus Menurut Injil Sinoptik Dalam Pelaksanaan Pendidikan Agama Kristen Di SMA Gamaliel Makassar." Jurnal Jaffray (2011).

Arifianto, Yonatan Alex. "Pentingnya Pendidikan Kristen Dalam Membangun Kerohanian Keluarga Di Masa Pandemi Covid-19." Regula Fidei Jurnal Pendidikan Agama Kristen 5, no. 2 (2020): 94-106.

Chusna, Puji Asmaul. "Pengaruh Media Gadget Pada Perkembangan Karakter Anak." Dinamika Penelitian: Media Komunikasi Sosial Keagamaan 17, no. 2 (2017): 315-330.

Darmawan, I Putu Ayub, and Diana Kristanti. "Penerapan Model Pembelajaran Picture and Picture Dalam Pembelajaran Di Sekolah Minggu." REGULA FIDEI: Jurnal Pendidikan Agama Kristen 5, no. 1 (2020): 1-12.

Eliasaputra, Mark Phillips, Martina Novalina, and Ruth Judica Siahaan. “Tantangan Pendidikan Agama Kristen Di Era Revolusi Industri 4.0 Dan Pasca Kebenaran." BONAFIDE: Jurnal Teologi dan Pendidikan Kristen 1, no. 1 (2020): $1-22$.

Ermindyawati, Lilis. "Peranan Guru Pendidikan Agama Kristen Terhadap Perilaku Siswa-Siswi Di SD Negeri 01 Ujung Watu Jepara." FIDEI: Jurnal Teologi Sistematika dan Praktika 2, no. 1 (2019): 40-61.

Fathurrohman, Muhammad. “Model-Model Pembelajaran.” Universitas Negeri Yogyakarta. Jogjakarta: Ar-Ruzz Media. Retrieved from (2015).

Ford, Leroy. A Primer For Teaching and Leaders. Bandung: Lembaga Literatur Baptis Indonesia, 1998.

GP, Harianto. Pendidikan Agama Kristen Dalam Alkitab Dan Dunia Pendidikan Masa Kini. Yokyakarta: Penerbit Andi, 2012.

Gunarsa, Singgih D. Psikologi Praktis Anak, Remaja,Dan Keluarga. Jakarta: BPK Gunung Mulia, 2004.

Hastuti, Ruwi. "Pendidikan Agama Kristen Dalam Keluarga Sebagai Pusat Bermisi." Jurnal Antusias 2, no. 4 (2013): 23-68. 
Intarti, Esther Rela. "Peran Guru Pendidikan Agama Kristen Sebagai Motivator." Regula Fidei 1, no. 2 (2016): 28-40.

Karnawati, Hosana, and I Putu Ayub Darmawan. “Lingkungan Proses Pembelajaran Yesus." Veritas Lux Mea: Jurnal Teologi dan Pendidikan Kristen 1, no. 2 (2019): 76-89. http:/ /jurnal.sttkn.ac.id/index.php/Veritas/article/view/46/pdf.

Kristiani, Dina. “Implementasi Model Teaching Learning Menurut Injil Matius Terhadap Guru-Guru Pendidikan Agama Kristen Di Kota Surakarta." Jurnal Pendidikan Agama Kristen 3, no. 1 (2018): 438-458.

- - - . "Implementasi Model Teaching Learning Tuhan Yesus Menurut Injil Matius Terhadap Guru-Guru Pendidikan Agama Kristen Di Kota Surakarta." Regula Fidei: Jurnal Pendidikan Agama Kristen 3, no. 1 (2018): 1-21.

Kuhns, Janet. "Mengajar Secara Kreatif." Jurnal Jaffray 1, no. 1 (January 5, 2005): 90. http://ojs.sttjaffray.ac.id/index.php/JJV71/article/view/171.

Nainggolan, Jhon M. Menjadi Agama Kristen, Bandung: Generasi Info Media, 2007.

Nainggolan, John M. PAK Dalam Masyarakat Majemuk. Bandung: Bina Media Informasi, 2009.

Notosoedirjarjo, Moeljono. Kesehatan Mental, Konsep Dan Penerapan. Malang: UMM Press, 2014.

Nuh, Semion, I Putu Ayub Darmawan, and Edi Sujoko. "Implementasi Pak Konteks Gereja Di Gkii Tandang, Semarang." Pengarah: Jurnal Teologi Kristen 1, no. 1 (2019): 59-70.

Nuhamara, Daniel. Pembimbing PAK. Bandung: Jurnal Info Media, 2007.

Oci, Markus. "Strategi Pembelajaran Pendidikan Agama Kristen." Sanctum Domine: Jurnal Teologi 2, no. 1 (2019): 143-160.

Priansa, and Doni Juni. Pengembangan Strategi Dan Model Pembelajaran. bandung: CV Pustaka Setia, 2017.

Rantesalu, Marsi Bombongan, and Hesti Arista Dara. "Penerapan Model Pembelajaran Yesus Dalam Matius 7:24-29 Terhadap Hasil Belajar Siswa Di Smpn 12 Kota Kupang." EDULEAD: Journal of Christian Education and Leadership 1, no. 1 (2020): 92-107.

Rifai. "Pendidikan Kristen Dalam Membangun Karakter Remaja Di Sekolah Menengah." Antusias-Jurnal Teologi dan Pelayanan 2, no. 2 (2012): 1-17.

Sagala, Lenda Dabora. "Peran Pendidikan Agama Kristen Dalam Menghadapi Perubahan Sosial." Jurnal Simpson: Jurnal Teologi dan Pendidikan Agama Kristen 1, no. 1 (2017): 48.

sairin weinata. Identitas $\mathcal{E}$ Ciri Khas Pendidikan Kristen Di Indonesia. jakarta: BPK Gunung Mulia, 2010.

Santosa, Donald Samuel Slamet, Donna Sampaleng, and Abdon Amtiran.

"Meningkatkan Prestasi Belajar Siswa Melalui Model Pembelajaran." SIKIP: Jurnal Pendidikan Agama Kristen 1, no. 1 (2020): 11-24.

Saptono Yohanes Joko. "Motivasi Dan Keberhasilan Belajar Siswa." Jurnal pendidikan agama kristen I, no. 1 (2016): 189-212.

Simanjuntak, Junihot M. “Belajar Sebagai Identitas Dan Tugas Gereja.” Jurnal Jaffray 16, no. 1 (2018): 1.

Sinlae, Ronald Yohanes. "Kompetensi Pedagogik Tuhan Yesus Dalam Injil Matius Pasal 5-7." Excelsis Deo: Jurnal Teologi, Misiologi, dan Pendidikan 4, no. 1 (2019): 
35-55.

Stefanus, Daniel. Pendidikan Agama Kristen Kemajemukan. bandung: BMI Bina Media Informas, 2009.

Sutoyo, Daniel. "Implementasi Metode Pengajaran Tuhan Yesus Dalam Injil-Injil." Antusias: Jurnal Teologi dan Pelayanan 1, no. 1 (2011): 41-96.

T Umar and S. L. La Sulo. Pengantar Pendidikan. Jakarta: Rineka Cipta, 2005.

Umrati, and Hengki Wijaya. Analisis Data Kualitatif Teori Konsep Dalam Penelitian Pendidikan. Sulawesi Selatan: Sekolah Tinggi Theologia Jaffray, 2020.

Warren, Rick. The Purpose Driven Church. Malang: Gandum Mas, 2004. 